\title{
Syzygium cumini inhibits growth and induces apoptosis in cervical cancer cell lines: a primary study
}

\author{
D Barh and G Viswanathan
}

Cancer Research Group, IHMA, Tamil Nadu 613006, India

\begin{abstract}
Cervical cancer is common among women in the Indian subcontinent and the incidences and death rates are gradually increasing over the years. Several dietary phytochemicals have been reported to have growth inhibitory and apoptotic effect on HeLa and other cervical cell lines. In this study, using Hoechst 33342 staining, MTT, Annexin V-FLUOS/PI and TUNEL assays we demonstrated that Syzygium cumini extract inhibits the growth and induces apoptosis in HeLa and SiHa cervical cancer cell lines in a dose- and time-dependent manner. The phytochemical, its mode of action and safety issues are yet to be determined.
\end{abstract}

Published: 21/08/2008

Received: 29/04/2008

ecancer 2008, 2:83 DOI: 10.3332/ecancer.2008.83

Copyright: (c) the authors; licensee ecancermedicalscience. This is an Open Access article distributed under the terms of the Creative Commons Attribution License (http://creativecommons.org/licenses/by/2.0), which permits unrestricted use, distribution, and reproduction in any medium, provided the original work is properly cited.

Competing Interests: The authors have declared that no competing interests exist.

Correspondence to D Barh. Email: dr.barh@gmail.com 


\section{Introduction}

Cervical cancer is the second most common cancer in women worldwide [1] with about a half-million new cases diagnosed each year [2]. According to the Indian National Cancer Registry Programme of the ICMR (1997), cervical cancer is the most common cancer in Indian women, followed by breast, oesophagus, ovary and stomach (Table 1) and the incidence is increasing, with an estimated rate of 100,000 new cases per year [3]. Standard treatment for cervical cancer, that is surgery along with taxol chemotherapy, often results in severe myelotoxicity and neurotoxicity $[4,5]$. On the contrary, the strategy of targeted apoptosis to neoplastic cells [6] using dietary phytochemicals having immunostimulative, antioxidant, anti-neoplastic, apoptotic and other physiological benefits are showing promising results in in vitro studies for several cancers.

Apoptotic and growth inhibitory effects of curcumin [7-10], aloe emodin [11], resveratrol [12-18], retinoic acid [19-22], lycopene $[23,24]$ and the tea polyphenol EGCG [25-28] in HeLa and other cervical cancer cell lines is well documented.

In this study, we evaluated the potential growth inhibitory and apoptotic effects of Syzygium cumini extract on two cervical cancer cell lines (HeLa and SiHa).

\section{Materials and methods}

\section{Syzygium cumini extract}

Crude extracts were isolated from wild-type partially ripe fruit skin along with the outermost layer of the berry, and then serial dilutions of the extract from $100 \%$ to $10 \%$ were made using PBS for MTT assays. Methanol extracts were prepared for other experiments by blending $5 \mathrm{~g}$ of skin with $50 \mathrm{ml}$ of methanol at $4^{\circ} \mathrm{C}$. After incubation at $37^{\circ} \mathrm{C}$ for 15 minutes, the extract was centrifuged at $3000 \mathrm{rpm}$ for 10 minutes at $4^{\circ} \mathrm{C}$. The supernatant was filtered, and the filtrate was vacuum dried and stored at $4^{\circ} \mathrm{C}$. For use the dried extract was dissolved in DMSO and diluted with culture medium to a final concentration of $80 \%(\mathrm{v} / \mathrm{v})$.

\section{Cell culture}

Human cervical carcinoma cell lines HeLa (HPV-18 positive) and $\mathrm{SiHa}$ (HPV-16 positive) were cultured in DMEM medium (supplemented with 10\% FBS, $2 \mathrm{mM}$ glutamine, $100 \mathrm{IU} / \mathrm{ml}$ penicillin, and $100 \mu \mathrm{g} / \mathrm{ml}$ streptomycin) in 96 -well plates at $37^{\circ} \mathrm{C}$ with $5 \% \mathrm{CO}_{2}$ and air humidity $95 \%$. Exponentially, growing cells were used for experiments.

A haemocytometer was used for cell counting using the formula:

Average count/4 $4104 \times 10$ (dilution factor) $=1.05 \times 106$ cells/ml

Total number of cells $=1.05 \times 106$ cells $/ \mathrm{ml} \times 5 \mathrm{ml}=5.25 \times 107$ cells

\section{MTT assay}

The cytotoxic effect of Syzygium cumini crude extract on HeLa and $\mathrm{SiHa}$ cells was initially determined by MTT assay. In a 96well plate, $0.25 \mathrm{ml}$ cultures were added to $0.1 \mathrm{ml}$ medium and incubated for two hours. Fifty $\mu$ of $100 \%$ or $10 \%$ extract were added to specific test wells; $50 \mu$ PBS was used as a control. After 24 hours of culture $100 \mu \mathrm{l}$ of MTT solution $(5.0 \mathrm{mg} / \mathrm{ml})$ was added to each well and left for 90 minutes. Culture were then washed with $0.1 \mathrm{ml}$ of $10 \%$ SDS in a low-speed shaker for 3 hours and then centrifuged at $100 \mathrm{rpm}$ for 5 minutes. The absorbance of $0.9 \mathrm{ml}$ of cell supernatant was read at $570 \mathrm{~nm}$ against a blank (medium alone). The growth inhibition was measured using the following formula:

Percentage inhibition $=[$ A570 (control) $-A 570$ (sample) $/$ A570(control)] $\times 100$.

The average growth inhibition percentages of triplicates are represented in Figure 1.

Morphological features of apoptosis were evaluated with Hoechst 33342 staining, TUNEL (terminal deoxynucleotidyl transferase (TdT)-catalysed dUTP-nick end labelling), and Annexin V-FLUOS/PI (Propidium Imidone) binding assays using phase contrast and fluorescence microscopy.

\section{Hoechst 33342 staining}

HeLa and $\mathrm{SiHa}$ cells seeded in chamber slides overnight were treated with $80 \%$ (v/v) Syzygium cumini extract. After 24, 36 and 48 hours of treatment, the medium was removed and the cells were washed twice with PBS. Cells were then fixed in $3 \%$ paraformaldehyde for 30 minutes, washed and stained with Hoechst $33342(10 \mu \mathrm{g} / \mathrm{ml})$ (Sigma) at $37^{\circ} \mathrm{C}$ for 30 minutes in the dark. After three washes with PBS, mounted slides were viewed 
Table 1: Leading cancers in population-based cancer registries under the National Cancer Registry Program of ICMR (1997) for women. Figures in parenthesis are crude incidence rates per 100,000

\begin{tabular}{|c|c|c|c|c|c|c|}
\hline Rank & Bangalore & Bhopal & Chennai & Delhi & Mumbai & $\begin{array}{l}\text { Barshi } \\
\text { (Rural) }\end{array}$ \\
\hline 1 & Breast (14) & Cervix (12.7) & Cervix (23.6) & Breast (19.8) & Breast (20.6) & Cervix (18.7) \\
\hline 2 & Cervix (13.8) & Breast (12.3) & Breast (21.4) & Cervix (15.8) & Cervix (12.1) & Breast (7.5) \\
\hline 3 & $\begin{array}{c}\text { Esophagus } \\
\qquad(3.8)\end{array}$ & Ovary (3.5) & $\begin{array}{c}\text { Stomach } \\
(4.6)\end{array}$ & Ovary (6.5) & Ovary (6.0) & $\begin{array}{c}\text { Esophagus } \\
(2.1)\end{array}$ \\
\hline 4 & $\begin{array}{c}\text { Stomach } \\
(3.1)\end{array}$ & $\begin{array}{l}\text { Esophagus } \\
\qquad(2.5)\end{array}$ & Ovary (4.4) & $\begin{array}{c}\text { Gall bladder } \\
(5.6)\end{array}$ & $\begin{array}{l}\text { Esophagus } \\
\qquad(3.9)\end{array}$ & Ovary (2.1) \\
\hline 5 & Ovary (2.9) & Mouth (2.5) & $\begin{array}{c}\text { Esophagus } \\
(4.2)\end{array}$ & $\begin{array}{l}\text { Lymphoma } \\
\quad(2.3)\end{array}$ & Lung (3.0) & Gum (1.2) \\
\hline
\end{tabular}

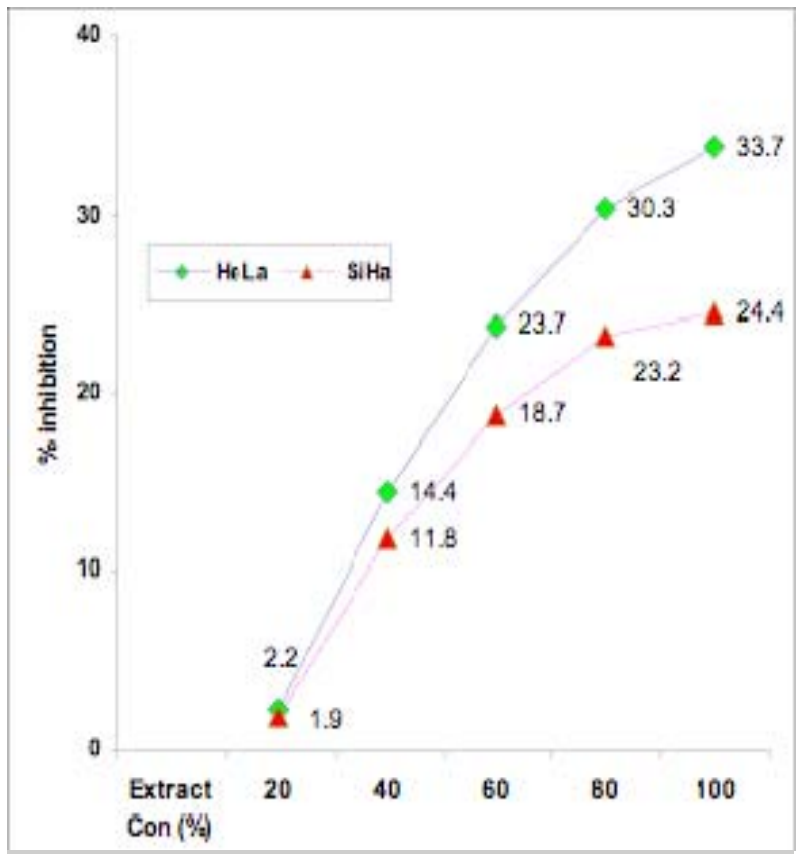

Figure 1: Effect of different concentrations of Syzygium cumini crude extract on growth inhibition of HeLa and SiHa cells, as determined by MTT assay. 


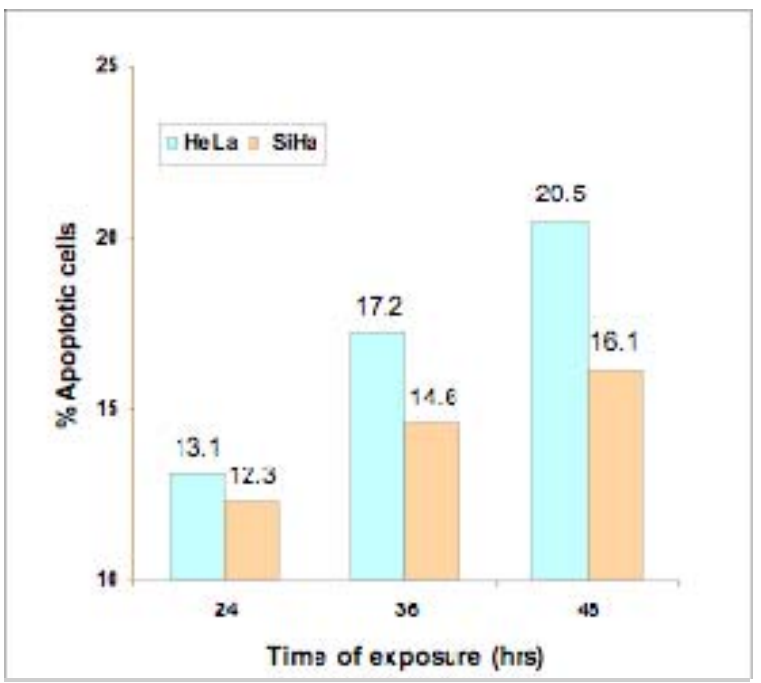

Figure 2: Effect of different exposure duration of Syzygium cumini methanolic extract on growth inhibition of HeLa and SiHa cells as determined by Hoechst 33342 staining.
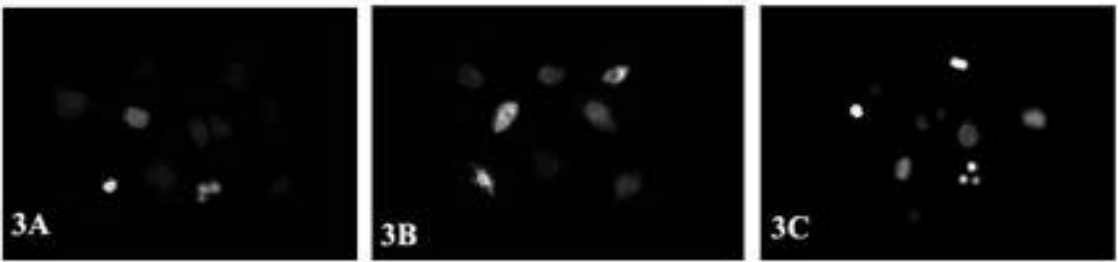

Figure 3: Effect of Syzygium cumini methanolic extract on growth inhibition of cervical cancer cell lines. (A) Hoechst 33342 staining for SiHa cells at $\mathbf{3 6}$ hours; (B) Annexin-V binding assay for HeLa cells at 48 hours; (C) TUNEL assay for SiHa cells at 48 hours.

under a fluorescence microscope at 450-490 $\mathrm{nm}$. The percentage of apoptotic cells was determined by cell counting, taking the mean count of five microscopic fields (Figure $3 \mathrm{~A}$ ).

\section{Annexin V-FLUOS/PI assay}

Annexin V-FLUOS/PI Staining Kit (Roche diagnostic) was used to determine membrane morphology of treated cells according to the manufacturer's protocol. Briefly, cells were washed with PBS and resuspended in binding buffer $(2.5 \mathrm{mM} \mathrm{CaCl} 2,140$ $\mathrm{mM} \mathrm{NaCl}, 10 \mathrm{mM}$ Hepes- $\mathrm{NaOH}, \mathrm{pH}$ 7.4) followed by the addition of fluorescence conjugated Annexin- $\mathrm{V}(1 \mu \mathrm{g} / \mathrm{ml})$ and 5 $\mu \mathrm{g} / \mathrm{ml} \mathrm{PI}$ and then a 30 minute incubation in the dark. Cells were observed under a fluorescence microscope at $488 \mathrm{~nm}$.

\section{TUNEL assay}

TUNEL assay was performed using an in situ Cell Death Detection Kit (Roche diagnostic), following the manufacturer's guidelines. In brief, cells were fixed with $4 \%$ paraformaldehyde and permeabilized $(0.1 \%$ sodium citrate and $0.1 \%$ Triton $\mathrm{X}-100)$ after washing. Cells were then rewashed and incubated with the TUNEL assay reaction mixture for 1 hour at $37^{\circ} \mathrm{C}$ and $95 \%$ air humidity. Samples were then analysed under a fluorescence microscope at $488 \mathrm{~nm}$.

\section{Results}

A prominent growth inhibitory effect of Syzygium cumini extract on these two cervical cell lines was observed. Different 
dilutions of the extract exhibited growth inhibition in a dosedependent manner in both cell lines tested with the MTT assay. While the $40 \%$ concentration of the extract exhibited $14.4 \%$ (HeLa) and 11.8\% (SiHa) growth inhibition, the $80 \%$ concentrated extract showed $30.3 \%$ and $23.2 \%$ growth inhibition, respectively, in HeLa and SiHa cell lines. The 100\% concentration did not show any significant effect over the $80 \%$ concentration. These results also indicate that the extract is more effective on HeLa than on SiHa cells (Figure 1).

Hoechst 33342 staining indicated condensed chromatin, the characteristic pattern of apoptosis, for both the cell lines under experiment. The apoptotic indices for these cell lines were calculated as mentioned earlier. It has been observed that a gradual increase of apoptotic index followed according to the treatment duration. Apoptotic cell counts were carried out at 24 hours (HeLa: $13.1 \%$, SiHa: $12.3 \%$ ), at 36 hours (HeLa: $17.2 \%$, SiHa: $14.6 \%$ ) and at 48 hours (HeLa: $20.5 \%$, SiHa: 16.1\%) (Figure 2). It has also been noticed that the methanolic extract was less effective as compared to the crude extract at the same concentration and the same exposure time. The result for $\mathrm{SiHa}$ is shown in (Figure 3A).

To distinguish the nuclear and membrane changes of the cells during apoptosis and also to investigate the necrotic cell death simultaneously, dual staining of cells with Annexin- $\mathrm{V}$ and PI was carried out with Annexin-V FLUOS/ PI staining. No PI staining was observed after 24 hours treatment, ruling out the possibility of necrosis, but fluorescence due to Annexin- $V$ binding to phosphatidylserine on the outer cell membrane of the apoptotic cells was observed. Figure 3B represents the Annexin- $V$ binding assay for HeLa cells at 48 hours.

The TUNEL assay was performed to detect the DNA strand breaks associated with apoptosis. The typical DNA strand breaks were detected in apoptotic cells after 24 hours treatment as strong fluorescence; these were absent in controls. Figure $3 \mathrm{C}$ ) represents the TUNEL assay micrograph for SiHa cells at 48 hours.

\section{Discussion}

Cervical cancer is the second cause of death from cancer in women worldwide, and the pathogenesis is well identified [2931]. The treatment options generally followed are mainly surgery with or without adjuvant radiotherapy and chemotherapy [32-34], which often results in severe side effects.
Medicinal plants play a major role in folk medicine in several developing countries. The dietary bioactive phytochemicals, namely curcumin, resveratrol, emodin, retinoic acid, lycopene, EGCG, and indole-3-carbinol, are not only anti-cancerous, antiproliferetive and apoptotic but also have antioxidant, antidiabetic, anti-mutagenic and various other physiological benefits and so represent a potential alternative to conventional chemotherapy and radiotherapy for cervical cancer. The screening of medicinal plants for potential anti-cancer properties has increased greatly over the years.

Syzygium cumini of the Myrtaceae family contains bergenin (an isocoumarin) [35], myricetin (a flavonol) and several polyphenols [36,37], tannins, http://www.herbs2000.com/h menu/tannins.htm alkaloids (Jambosine), triterpenoids and volatile oils. Various parts of the plant are used for treatment of a variety of human abnormalities. The seed is able to lower blood glucose rapidly and so is effective in treating diabetes $[38,39]$ and hyperinsulinemia [40]. Seed extracts are rich in phenols and show high-antioxidant activity [41]. It inhibits gastric ulceration [42], protects from gamma radiation [43], reduces the damage to brain tissue of diabetics [44] and also inhibits alphaglucosidase activity [45]. The leaf extract has anti-fungal properties [46] and is anti-hyperglycemic and lowers blood glucose level in type 2 diabetes $[47,48]$. It reduces radiationinduced DNA damage in cultured human lymphocytes [49], can dissolve human gallbladder stones in vitro [50], protects from carbon tetrachloride-induced hepatotoxicity [51] and inhibits goatpox virus replication [52]. Its anti-allergic and antiedematogenic effect is brought about by inhibiting histamine, serotonin, CCL11, IL-5 and mast cell degranulation [53]. Essential oils from the leaf have been reported to have antibacterial activity [54] and the bark has anti-inflammatory [55], gastroprotective [56] and anti-diarrhoeal [57] activities. The fruit skin has been reported to have antioxidant activity [58] and the fruit pulp an anti-hyperglycemic effect [59].

This study shows that extract of Syzygium cumini fruit skin along with the outermost layer of the berry inhibits growth and induces apoptosis in both HeLa and SiHa cervical cancer cell lines in a dose- and time-dependent manner. Whereas the crude extract exhibited, respectively, $33.7 \%$ and $24.4 \%$ growth inhibition in HeLa and SiHa cells at its highest concentration $(100 \%)$ in MTT assay, the methanolic extract $(80 \% \mathrm{v} / \mathrm{v})$ showed an apoptotic index of $20.5 \%$ and $16.1 \%$, respectively, for these cell lines as determined by Hoechst 33342 staining. It has also been found that the crude extract is more effective in growth inhibition and apoptosis than the methanolic extract at its most effective concentration (80\%). Annexin- $V$ binding and TUNEL assays also confirm the apoptotic effect of the extract. 


\section{Conclusion}

In conclusion, the study confirms a dose- and time-dependent growth inhibitory and apoptotic effect of Syzygium cumini extract on the cervical cancer cell lines HeLa (HPV-18 positive) and $\mathrm{SiHa}$ (HPV-16 positive). Syzygium cumini fruit contains gallic acid, which has anti-adenoviral, anti-HIV, anti-peroxidant, anti-carcinomic, apoptotic and chemopreventive activities and is a topoisomerase-I-inhibitor (Dr Duke's Phytochemical and
Ethnobotanical Databases: http://www.ars-grin.gov/duke/). Though the results of this study indicate the growth inhibitory and apoptotic effect of the extract, the chemical component(s) responsible for these phenomena is/are yet to be precisely identified. Similarly, the anti-viral effect in respect to HPV-18 and HPV-16 is yet to be confirmed by further experiments. Moreover, further research is needed to identify the mode of action, efficacy and safety issues. 


\section{References}

1. Krauss T, Huschmand NA, Viereck V and Emons G (2001) New developments in the treatment of cervical cancer Onkologie $24 \quad 4$ 340-5 PMD 11574761 doi: 10.1159/ $\underline{000055105}$

2. Shanta V, Krishnamurthi S, Gajalakshmi CK, Swaminathan $R$ and Ravichandran K (2000) Epidemiology of cancer of the cervix: global and national perspective $\mathrm{J}$ Indian Med Assoc 982 49-52 PMID 11016150

3. Sinha R, Anderson DE, McDonald SS and Greenwald P (2003) Cancer Risk and Diet in India J Postgrad Med 49 3 222-8 PMID 14597785

4. Maier-Lenz H, Hauns B, Haering B, Koetting J et al (1997) Phase I study of paclitaxel administered as a 1-hour infusion: toxicity and pharmacokinetics Semin Oncol 24 6 Suppl 19 S19-16-S19-19 PMID 9427259

5. Zanetta G, Fei F and Mangioni C (2000) Chemotherapy with paclitaxel, ifosfamide, and cisplatin for the treatment of squamous cell cervical cancer: the experience of Monza Semin Oncol 271 Suppl $123-7$ PMID 10697040

6. Fan S, Cherney B, Reinhold W, Rucker K and O'Connor PM (1998) Disruption of P53 function in immortalized human cells does not affect survival or apoptosis after Taxol or Vincristine treatment Clin Cancer Res 44 104754 PMID 9563901

7. Bava SV, Puliappadamba VT, Deepti A, Nair A et al (2005) Sensitization of taxol-induced apoptosis by curcumin involves down-regulation of nuclear factor-kappaB and the serine/threonine kinase Akt and is independent of tubulin polymerization $\mathrm{J} \mathrm{Biol} \mathrm{Chem} 2808$ 6301-8 PMID 15590651 doi: $10.1074 / j b c . M 410647200$

8. Prusty BK and Das BC (2005) Constitutive activation of transcription factor AP-1 in cervical cancer and suppression of human papillomavirus (HPV) transcription and AP-1 activity in HeLa cells by curcumin Int J Cancer 1136 951-60 PMID 15514944 doi: $\underline{10.1002 / i j c .20668}$

9. Kamath R, Jiang Z Sun G, Jack CY and Baskaran R (2007) c-Abl kinase regulates curcumin-induced cell death through activation of c-Jun $\mathrm{N}$-terminal Kinase $\mathrm{Mol}$ Pharmacol 71 1 61-72 PMID 17021249 doi: 10.1124/mol. $\underline{106.026575}$

10. Novak Kujundzić R, Grbesa I, Ivkić M, Katdare M and GallTroselj K (2008) Curcumin downregulates H19 gene transcription in tumor cells J Cell Biochem 1045 178192 PMID 18348204 doi: $10.1002 / j \mathrm{jcb} .21742$

11. Srinivas G, Anto RJ, Srinivas P, Vidhyalakshmi S, Senan VP and Karunagaran D (2003) Emodin induces apoptosis of human cervical cancer cells through
poly(ADP-ribose) polymerase cleavage and activation of caspase-9 Eur J Pharmacol 473 2-3 117-125 PMID 12892828 doi: $10.1016 / S 0014-2999(03) 01976-9$

12. Manna SK, Mukhopadhyay A and Aggarwal BB (2000) Resveratrol suppresses TNF-induced activation of nuclear transcription factors NF-kappa B, activator protein-1, and apoptosis: potential role of reactive oxygen intermediates and lipid peroxidation $\mathrm{J}$ Immunol 16412 6509-19 PMID 10843709

13. Yu R, Hebbar V, Kim DW, Mandlekar S, Pezzuto JM and Kong AT (2001) Resveratrol Inhibits Phorbol Ester and UV-Induced Activator Protein 1 Activation by Interfering with Mitogen-Activated Protein Kinase Pathways Mol Pharmacol $601217-24$ PMID 11408617

14. Yoon SH, Kim YS, Ghim SY, Song BH and Bae YS (2002) Inhibition of protein kinase CKII activity by resveratrol, a natural compound in red wine and grapes Life Sci 71 18 2145-52 PMID 12204772 doi: 10.1016/S0024-3205(02) $\underline{01997-5}$

15. Baatout S, Derradji H, Jacquet P, Ooms D et al (2004) Enhanced radiation-induced apoptosis of cancer cell lines after treatment with resveratrol Int J Mol Med 136 895-902 PMID 15138632

16. Liu S, Hu Y, Wang $X$, Zhong J and Lin Z (2006) High content of resveratrol in lettuce transformed with a stilbene synthase gene of Parthenocissus henryana $\mathrm{J}$ Agric Food Chem 5421 8082-5 PMID 17032013 doi: $\underline{10.1021 / \mathrm{jf0} 01462 \mathrm{k}}$

17. Sexton E, Van Themsche C, LeBlanc K, Parent S et al (2006) Resveratrol interferes with AKT activity and triggers apoptosis in human uterine cancer cells $\mathrm{Mol}$ Cancer 5 45-9 PMID 17044934 doi: 10.1186/1476-4598-5$\underline{45}$

18. Tang X, Zhang Q, Nishitani J, Brown J, Shi S and Le AD (2007) Overexpression of human papillomavirus type 16 oncoproteins enhances hypoxia-inducible factor 1 alpha protein accumulation and vascular endothelial growth factor expression in human cervical carcinoma cells Clin Cancer Res 139 2568-76 PMID 17473185 doi: 10.1158/1078-0432.CCR-06-2704

19. Tillmanns TD, Kamelle SA, Guruswamy S, Gould NS, Rutledge TL and Benbrook DM (2005) Sensitization of cervical cancer cell lines to low-dose radiation by retinoic acid does not require functional p53 Gynecol Oncol 971 142-50 PMID 15790450 doi: 10.1016/j.ygyno. $\underline{2004.12 .034}$

20. Borutinskaite $\mathrm{VV}$, Navakauskiene $\mathrm{R}$ and Magnusson KE (2006) Retinoic acid and histone deacetylase inhibitor BML-210 inhibit proliferation of human cervical cancer HeLa cells Ann N Y Acad Sci 1091 346-55 PMID 17341627 doi: $10.1196 /$ annals. 1378.079 
21. Guo JM, Xiao BX, Kang GZ, Liu DH, Chen H, Zhang S and Zhang XN (2006) Suppression of telomerase activity and arrest at G1 phase in human cervical cancer HeLa cells by all-trans retinoic acid Int J Gynecol Cancer 161 341-6 PMID 16445656 doi: 10.1111/j.1525-1438.2006. 00353.x

22. Yokoyama $M$, Noguchi $M$, Nakao $Y$, Ysunaga $M$ et al (2008) Antiproliferative effects of the major tea polyphenol, (-)-epigallocatechin gallate and retinoic acid in cervical adenocarcinoma Gynecol Oncol 1082 326-31 PMID 18035403 doi: 10.1016/j.ygyno.2007.10.013

23. Kanetsky PA, Gammon MD, Mandelblatt J, Zhang ZF et al (1998) Dietary intake and blood levels of lycopene: association with cervical dysplasia among nonHispanic, black women Nutr Cancer 31 1 31-40 PMID $\underline{9682246}$ doi: $10.1080 / 01635589809514675$

24. Brewer J, Benghuzzi $H$ and Tucci M (2006) Effects of thymoquinone, lycopene, and selenomethione in the presence of estrogen on the viability of SiHa cells in vitro Biomed Sci Instrum 42 37-41 PMID 16817582

25. Ahn WS, Huh SW, Bae SM, Lee IP et al (2003) A major constituent of green tea, EGCG, inhibits the growth of a human cervical cancer cell line, CaSki cells, through apoptosis, $\mathbf{G ( 1 )}$ arrest, and regulation of gene expression DNA Cell Biol 223 217-24 PMID 12804120 doi: $10.1089 / 104454903321655846$

26. Sah JF, Balasubramanian S, Eckert RL and Rorke EA (2004) Epigallocatechin-3-gallate inhibits epidermal growth factor receptor signaling pathway. Evidence for direct inhibition of ERK1/2 and AKT kinases $\mathrm{J} \mathrm{Biol}$ Chem 27913 12755-62 PMID 14701854 doi: 10.1074/jbc. M312333200

27. Yokoyama M, Noguchi M, Nakao Y, Pater A and Iwasaka T (2004) The tea polyphenol, (-)-epigallocatechin gallate effects on growth, apoptosis, and telomerase activity in cervical cell lines Gynecol Oncol 921 197-204 PMID 14751158 doi: $10.1016 /$ j.ygyno.2003.09.023

28. Noguchi M, Yokoyama M, Watanabe S, Uchiyama M et al (2006) Inhibitory effect of the tea polyphenol, (-)epigallocatechin gallate, on growth of cervical adenocarcinoma cell lines Cancer Lett 2342 135-42 PMID 15907368 doi: 10.1016/j.canlet.2005.03.053

29. Zur Hausen H (1991) Human papillomavirus in pathogenesis of anogenital cancer Virology 184 1 9-13 $\underline{\text { PMID } 1651607}$ doi: 10.1016/0042-6822(91)90816-T

30. Schiffman MH (1992) Recent progress in defining the epidemiology of human papillomavirus infection and cervical neoplasia J Natl Cancer Inst 846 394-7 PMID 1311392 doi: 10.1093/jnci/84.6.394

31. Rock CL, Michael CW, Reynolds RK and Ruffin MT (2000) Prevention of cervix cancer Crit Rev Oncol Hematol 333
169-85 PMID 10789491 doi: 10.1016/S1040-8428(99) $\underline{00073-6}$

32. Thigpen JT, Vance R, Puneky L and Khansur T (1995) Chemotherapy as a palliative treatment in carcinoma of the uterine cervix Semin Oncol 222 Suppl 3 16-24 PMID $\underline{7537898}$

33. Sitt JA (1999) High dose rate brachytherapy in the treatment of cervical carcinoma Hematol Oncol Clin North Am 133 585-93 PMID 10432431 doi: 10.1016/ S0889-8588(05)70077-0

34. Grisby PW and Herzog TJ (2001) Current management of patients with invasive cervical carcinoma Clin Obstet Gynecol $44 \quad 3 \quad 531-7$ PMID 11685877 doi: 10.1097/ $\underline{00003081-200109000-00008}$

35. Kopanski $L$ and Schnelle G (1988) Isolation of Bergenin from Barks of Syzygium cumini Planta Med 546572 PMID 17265363 doi:10.1055/s-2006-962577

36. Mahmoud II, Marzouk MS, Moharram FA, El-Gindi MR and Hassan AM (2001) Acylated flavonol glycosides from Eugenia jambolana leaves Phytochemistry 588 1239-44 PMID 11738415 doi: 10.1016/S0031-9422(01)00365-X

37. Timbola AK, Szpoganicz B, Branco A, Monache FD and Pizzolatti MG (2002) A new flavonol from leaves of Eugenia jambolana Fitoterapia $73 \quad 2 \quad 174-6 \quad \underline{\text { PMID }}$ 11978436 doi: 10.1016/S0367-326X(02)00009-6

38. Prince PS, Kamalakkannan N and Menon VP (2004) Antidiabetic and antihyperlipidaemic effect of alcoholic syzygium cumini seeds in alloxan induced diabetic albino rats $J$ Ethnopharmacol 91 2-3 209-13 PMID 15120440 doi: 10.1016/i.jep.2003.11.001

39. Kochhar A and Nagi M (2005) Effect of supplementation of traditional medicinal plants on blood glucose in noninsulin-dependent diabetics: a pilot study J Med Food 8 4 545-9 PMID 16379570 doi: 10.1089/jmf.2005.8.545

40. Vikrant V, Grover JK, Tandon N, Rathi SS and Gupta N (2001) Treatment with extracts of Momordica charantia and Eugenia jambolana prevents hyperglycemia and hyperinsulinemia in fructose fed rats $\mathrm{J}$ Ethnopharmacol 762 139-43 PMID 11390126 doi: 10.1016/S0378-8741(01) 00218-5

41. Bajpai M, Pande A, Tewari SK and Prakash D (2005) Phenolic contents and antioxidant activity of some food and medicinal plants Int J Food Sci Nutr 564287 91 PMID 16096138 doi: 10.1080/09637480500146606

42. Chaturvedi A, Kumar MM, Bhawani G, Chaturvedi $\mathrm{H}$ et al (2007) Effect of ethanolic extract of Eugenia jambolana seeds on gastric ulceration and secretion in rats Indian J Physiol Pharmacol 512 131-40 PMID 18175656

43. Jagetia GC, Baliga MS and Venkatesh $P$ (2005) Influence of seed extract of Syzygium Cumini (Jamun) on mice 
exposed to different doses of gamma-radiation $\mathrm{J}$ Radiat Res (Tokyo) 461 59-65 PMID 15802860 doi: 10.1269/jrr. $\underline{46.59}$

44. Prince PS, Kamalakkannan N and Menon VP (2003) Syzygium cumini seed extracts reduce tissue damage in diabetic rat brain $J$ Ethnopharmacol 84 2-3 205-9 PMID 12648817 doi: 10.1016/S0378-8741(02)00316-1

45. Shinde J, Taldone T, Barletta M, Kunaparaju N, Hu B, Kumar S, Placido J and Zito SW (2008) AlphaGlucosidase inhibitory activity of Syzygium cumini (Linn.) Skeels seed kernel in vitro and in Goto-Kakizaki (GK) rats Carbohydr Res 3437 1278-81 PMID 18374320 doi: 10.1016/j.carres.2008.03.003

46. Braga FG, Bouzada ML, Fabri RL, de O Matos M, Moreira FO, Scio E and Coimbra ES (2007) Antileishmanial and antifungal activity of plants used in traditional medicine in Brazil J Ethnopharmacol 1112 396-402 PMID 17234373 doi: 10.1016/j.jep.2006.12.006

47. Oliveira $A C$, Endringer DC, Amorim LA, das Graças $L$ Brandão $M$ and Coelho MM (2005) Effect of the extracts and fractions of Baccharis trimera and Syzygium cumini on glycaemia of diabetic and non-diabetic mice J Ethnopharmacol 1023 465-9 PMID 16055289 doi: 10.1016/j.jep.2005.06.025

48. Teixeira CC and Fuchs FD (2006) The efficacy of herbal medicines in clinical models: the case of jambolan $J$ Ethnopharmacol 1081 16-9 PMID 16963214 doi: 10.1016/ j.jep.2006.07.032

49. Chandra G and Baliga MS (2002) Syzygium cumini (Jamun) reduces the radiation-induced DNA damage in the cultured human peripheral blood lymphocytes: a preliminary study Toxicol Lett 132 1-7 19-25 PMID 12084616

50. Das I, Singh Y, Shoeb A and Agrawal NR (2005) In vitro dissolution of gallbladder stone by edible leaves, fruits and homoeopathic medicines J Cryst Growth 283 3-4 508-13 doi: 10.1016/j.jcrysgro.2005.06.006

51. Moresco RN, Sperotto RL, Bernardi AS, Cardoso RF and Gomes P (2007) Effect of the aqueous extract of
Syzygium cumini on carbon tetrachloride-induced hepatotoxicity in rats Phytother Res $218793-5$ PMID 17450508 doi: $10.1002 /$ ptr.2158

52. Bhanuprakash V, Hosamani M, Balamurugan V, Gandhale $P$ et al (2008) In vitro antiviral activity of plant extracts on goatpox virus replication Indian J Exp Biol 462 120-7 PMID 18335810

53. Brito FA, Lima LA, Ramos MF, Nakamura MJ et al (2007) Pharmacological study of anti-allergic activity of Syzygium cumini (L.) Skeels Braz J Med Biol Res 401 105-15 PMID 17225003

54. Shafi PM, Rosamma MK, Jamil K and Reddy PS (2002) Antibacterial activity of Syzygium cumini and Syzygium travancoricum leaf essential oils Fitoterapia 735 414-6 PMID 12165339 doi: 10.1016/S0367-326X(02) $\underline{00131-4}$

55. Muruganandan S, Srinivasan K, Chandra S, Tandan SK et al (2001) Anti-inflammatory activity of Syzygium cumini bark Fitoterapia $72 \quad 4 \quad 369-75$ PMID 11395258 doi: 10.1016/S0367-326X(00)00325-7

56. Ramirez RO and Roa CC Jr (2003) The gastroprotective effect of tannins extracted from duhat (Syzygium cumini Skeels) bark on $\mathrm{HCl} /$ ethanol induced gastric mucosal injury in Sprague-Dawley rats Clin Hemorheol Microcirc 29 3-4 253-61 PMID 14724349

57. Mukherjee PK, Saha K, Murugesan T, Mandal SC, Pal M and Saha BP (1998) Screening of anti-diarrhoeal profile of some plant extracts of a specific region of West Bengal, India J Ethnopharmacol 601 85-9 PMID 9533436 doi: 10.1016/S0378-8741(97)00130-X

58. Banerjee A, Dasgupta N and De B (2005) In vitro study of antioxidant activity of Syzygium cumini fruit Food Chemistry 904 727-33 doi: 10.1016/j.foodchem.2004.04. $\underline{033}$

59. Sharma SB, Nasir A, Prabhu KM and Murthy PS (2006) Antihyperglycemic effect of the fruit-pulp of Eugenia jambolana in experimental diabetes mellitus $J$ Ethnopharmacol $104 \quad 3 \quad 367-73$ PMID 16386863 doi: 10.1016/j.jep.2005.10.033 